\title{
Antarctic Earth System Science in the International Polar Year 2007-2008
}

\author{
R. E. Bell
}

\begin{abstract}
The International Polar Year (IPY) 2007-2008 is the largest coordinated effort to understand the polar regions in our lifetime. This international program of science, discovery, and education involves more than 50,000 scientists from 62 nations. The IPY 2007-2008 Antarctic Earth System Science themes are to determine the polar regions' present environmental status, quantify and understand past and present polar change, advance our understanding of the links between polar regions and the globe, and investigate the polar frontiers of science. There are several key IPY 2007-2008 Earth System Science projects in the Antarctic:
\end{abstract}

- POLENET will capture the status of the polar lithosphere through new instrument arrays.

- ANDRILL will uncover past change using novel drilling technologies.

- "Plates and Gates" will advance our understanding of the teleconnections between Antarctica and the global climate system.

- AGAP and SALE-UNITED will study hitherto unsampled subglacial mountains and lakes.

A new era of international collaboration will emerge along with a new generation of Antarctic scientists and a legacy of data and enhanced observing systems.

'Lamont-Doherty Earth Observatory of Columbia University, Palisades, New York, 10964-8000, USA (robinb@1deo.columbia.edu).

\section{INTRODUCTION TO IPY 2007-2008}

Earth science revolves around the study of our changing planet. IPY 2007-2008 is motivated both by the need to improve our understanding of this changing planet and by a quest to explore still unknown frontiers, especially those beneath the vast Antarctic ice sheet. While intuitively we all appreciate that planetary change happens, as the concept of an international polar year emerged the evidence for rapid and dynamic planetary change was becoming omnipresent. Early in 2002 an ice shelf that had been stable for at least 20,000 years (Domack et al., 2005), the Larsen B Ice Shelf, collapsed in a matter of weeks (Scambos et al., 2004). This ice shelf collapse began to bring together the timescale of planetary change with the more familiar human timescale of days, week, and months.

By 2002 change in the polar regions was undeniable. The surface melt in Greenland was increasing in extent (Steffen et al., 2004), sea ice cover in the Arctic was beginning to decrease notably (Johannessen et al., 1999), the glaciers feeding the Weddell Sea accelerated after the Larsen Ice Shelf collapsed (Rignot et al., 2004; Scambos et al., 2004), and the Amundsen Sea sector of the West Antarctic ice sheet was thinning and accelerating (Joughin et al., 2003; Shepherd et al., 2004). The polar environments were clearly changing, and doing so rapidly. While change is being observed globally, the environmental change at the poles is taking place faster than environmental change anywhere else on the planet. The ramifications of these polar changes reach far beyond the Antarctic and Arctic, because as ice melts, sea levels rise. The need to understand the changes in the polar regions-past, present, and future-is imperative for our global society, the global economy, and the global environment, as well as being a fascinating scientific challenge in its 
own right. This overwhelming sense of rapid and increasing change, and what we can learn from it, especially in the polar regions where the change is fastest, is one of the major motivations for the development of the IPY (Albert, 2004).

Beyond the sense of planetary change, discovery is a keen motivator. In the 1800 s exploration was conducted by teams of men pressing for the poles, led by Nansen, Amundsen, Scott, and Shackleton. Nansen captured the essence of geographically motivated exploration, noting that humankind's spirit "will never rest till every spot of these regions has been trod upon" (Nansen and Sverdrup, 1897). Today we seek to push the frontiers of our knowledge of processes, rather than geographic frontiers. The community remains intensely motivated by Nansen's second restless quest, which is to seek knowledge "till every enigma has been solved." While Nansen sought to understand the circulation in the Arctic Ocean, today we see major opportunities for scientific discovery in Antarctic Earth science. Discovery is the second motivation for this IPY. The frontiers are no longer the geographic poles but the regions and processes hidden by kilometers of ice and water.

Propelled forward by the sense of planetary change and a sense of discovery, IPY 2007-2008 will be the largest internationally coordinated research program in 50 years, actively engaging over 50,000 scientists from 62 nations. The result of a five-year community-wide planning process, the IPY 2007-2008 will be an intensive period of interdisciplinary science focused on both polar regions- the Antarctic and the Arctic. The projects of the IPY 2007-2008 focus on deciphering these processes of change in the polar regions and their linkages with the rest of the globe while also exploring some of the final frontiers.

\section{FRAMEWORK}

Today in our global interconnected world, "year" events occur at a frenetic pace. For example, 2002 was the U.N. International Year of Mountains and 2005 was the U.N. Year of Physics. These U.N.-sponsored events tend to focus on celebration, awareness, and education. For instance, in parallel with the IPY 2007-2008, Earth scientists have developed the U.N. International Year of Planet Earth, a celebration of the role of Earth science in society. Awareness, celebration, and education have consistently been a key facet of all IPYs since 1882-1883, but the central framework for the polar years has always been to facilitate collaborative science at a level impossible for any individual nation.

The concept of collaborative international polar science focused on a specific period was developed by Lt. Karl Weyprecht, an Austrian naval officer. Weyprecht was a scientist and co-commander of the Austro-Hungarian North Pole Expedition that set off in 1872 in a three-masted schooner, the Admiral Tegetthoff. The expedition returned two years later without the schooner. The expedition had abandoned the ship frozen into the pack ice and hauled sledges over the pack ice for 90 days to the relative safety of open water. Weyprecht was acutely aware that the systematic observations necessary to advance the understanding of the fundamental problems of meteorology and geophysics were impossible for men hauling sledges across the ice and struggling to survive. His frustration with the inability to understand polar phenomena with the data from a single national expedition is captured in his "Fundamental Principles of Arctic Research" (Weyprecht, 1875). He noted that "whatever interest all these observations may possess, they do not possess that scientific value, even supported by a long column of figures, which under other circumstances might have been the case. They only furnish us with a picture of the extreme effects of the forces of Nature in the Arctic regions, but leave us completely in the dark with respect to their causes."

Weyprecht believed that the systematic successful study of the polar regions and large-scale polar phenomena by a single nation was impossible. He argued that fixed stations where coordinated observations could be made were necessary for consistency of measurements. Weyprecht's insights were central to the planning and execution of the first IPY.

A realization of Weyprecht's vision, the first IPY (18821883) involved 12 countries launching 15 expeditions to the poles: 13 to the Arctic and 2 to the Antarctic, using coal- and steam-powered vessels (Figure 1). At each station a series of

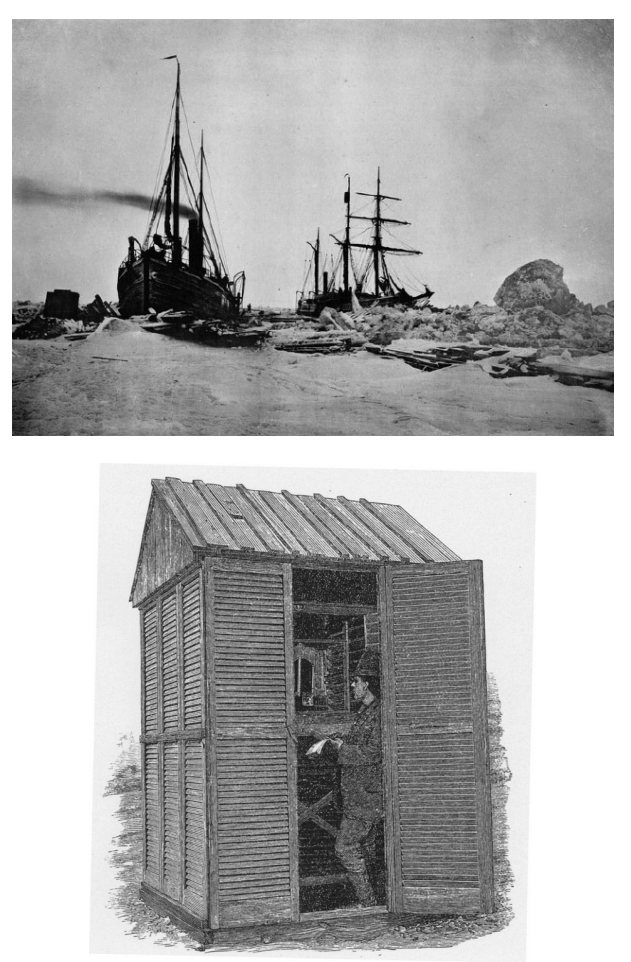

FIGURE 1 First International Polar Year. Top: Norwegian ship in the ice, Kara Sea (from Steen [1887]). Bottom: Observer making temperature observations at Fort Conger, 1882 (from Greely [1886]).

SOURCE: See http://www.arctic.noaa.gov/aro/ipy-1/US-LFBP4.htm. 


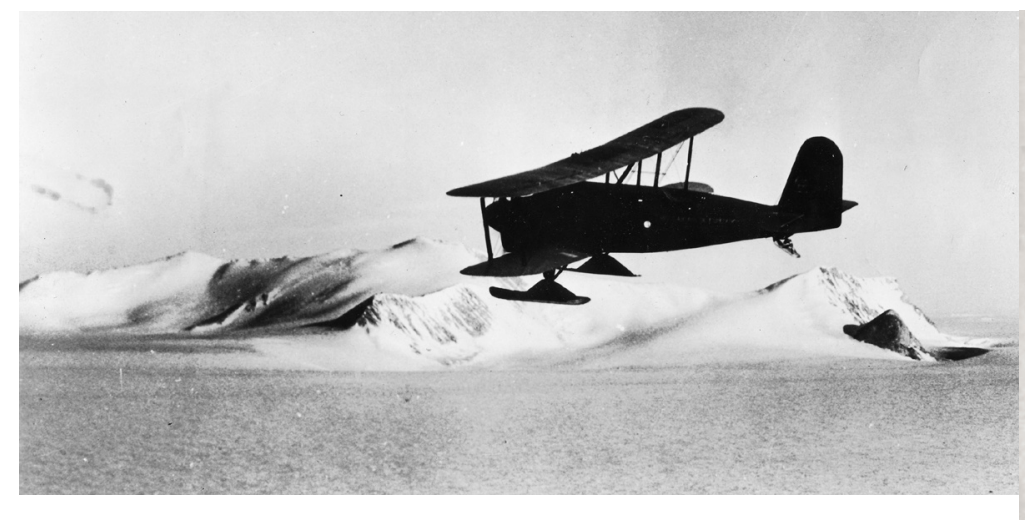

FIGURE 2 Second International Polar Year. Left: Aircraft in Antarctica (from the Ohio State University Archives, Papers of Admiral Richard E. Byrd, \#7842_18). Right: Launching a weather balloon in northern Canada (from the University of Saskatchewan Archives, 1931). regular observations were recorded with pencil and paper, from meteorology to Earth's magnetic field variations (Figure 1). Beyond the advances to science and geographical exploration, a principal legacy of the first IPY was setting a precedent for international science cooperation. The clear gap between Weyprecht's vision and the outcomes was that the data were never fully integrated and analyzed together (Wood and Overland, 2006).

During the first IPY (1882-1883) the Brooklyn Bridge opened in New York City, five years before the Eiffel Tower opened in Paris. Fifty years later the second IPY (19321933) began, and this was the year the Empire State Building opened in New York City. Routine flights by aircraft and wireless communication were both now possible. During the second IPY, 40 nations conducted Arctic research focusing on meteorology, magnetism, atmospheric science, and ionospheric physics. Forty permanent observation stations were established in the Arctic. The U.S. contribution to the second IPY was the second Byrd Antarctic expedition. The Byrd expedition established the first inland research station, a winter-long meteorological station on the Ross Ice Shelf at the southern end of Roosevelt Island. Scientists employed aircraft to extend the range of their observations and for the first time received data transmitted back from balloons as they drift upward, allowing the first vertical sampling of the polar atmosphere (Figure 2).

The third IPY expanded beyond the polar regions, quickly becoming global. This polar year was renamed the International Geophysical Year (IGY) and ran from July 1, 1957, to December 31, 1958 (see Figure 3). Coincident with the groundbreaking for the Sydney Opera House, the IGY was the brainchild of a small number of eminent physicists, including Sydney Chapman, James Van Allen, and Lloyd Berkner. These physicists realized that the technology developed during World War II, such as rockets and radar, could be deployed to advance science. Sixty-seven nations participated in the IGY. The IGY's research, discoveries, and vast array of synoptic observations set the stage for decades of geophysical investigations. Data collected from ships were used subsequently to advance the theory of plate tectonics, while satellites detected the Van Allen Radiation Belt. Seismic measurements collected along geophysical traverses measured the thickness of the Antarctic ice sheet, enabling the first estimates of Antarctica's ice mass. Emerging from the IGY was the Scientific Committee on Antarctic Research (SCAR) in 1958 and the Antarctic Treaty in 1961. Permanent stations were established for the first time in Antarctica as a direct result of the IGY.

At the end of the IGY, Hugh Odishaw, executive director of the U.S. National Committee, noted, "We have only scratched the surface of our ignorance with respect to Antarctic. . . . There is at hand an unparalleled situation for stimulating the best in man" (Odishaw, 1959). Having scratched the surface of Antarctica, scientists and engineers of 1958 handed the baton to our generation to bring together scientists and engineers to understand the role the poles play in our rapidly changing world. It is for us to explore the remaining frontiers using the cutting-edge technologies available to us today: jet aircraft, ships, satellites, lasers, the Global Positioning System (GPS), advanced communications, computers, numerical modeling, passive seismics, autonomous observatories, and novel coring technologies. 

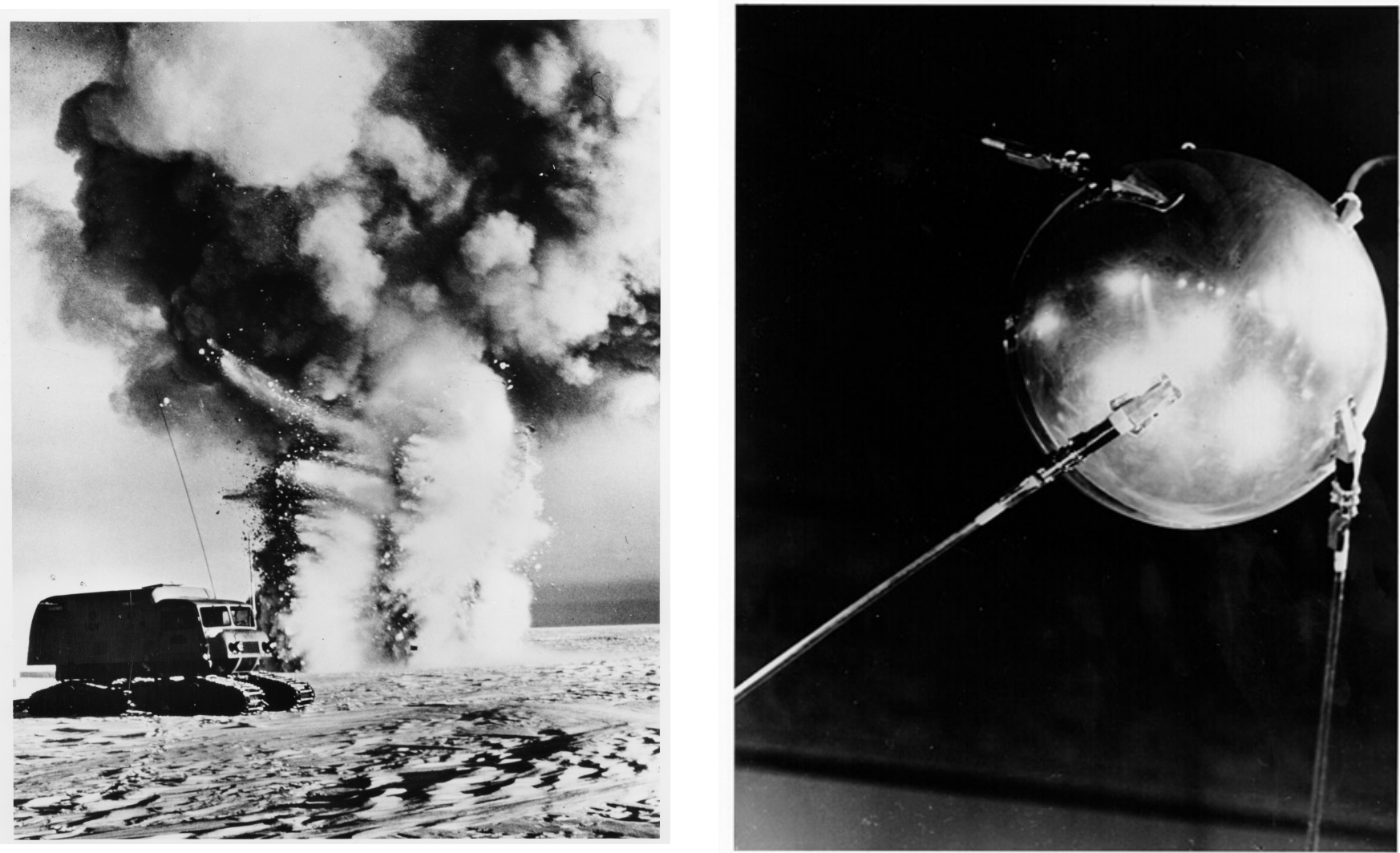

FIGURE 3 International Geophysical Year 1957-1958. Left: Geophysical traverse vehicle collecting seismic data at Byrd Station, West Antarctica (from http://www.nas.edu/history/igy/seismology.html). Right: Sputnik, the first satellite launched into space (image from NASA).

\section{IPY 2007-2008 PLANNING PROCESS}

The development of the IPY 2007-2008 began with an extended period of community education with scientists studying the accounts of the previous IPYs and discussing the results. The concept of another polar year emerged through discussions among communities and with funding agencies. Websites documenting the contributions of the first three IPYs were launched. These discussions were first documented in SCAR meeting reports in 2000. At the 2000 SCAR meeting in Tokyo, K. Erb, president of the Council of Managers of National Antarctic Programs, reported on discussions to "prepare for recognition of the 50th Anniversary of the International Polar Year." One year later the discussions were still on the margins, with a short note in the report from the SCAR executive meeting, under the title "Any Other Business." Again the focus was on celebration, not action. The Neumayer International Symposium in 2001 provided a further opportunity for the community to discuss the impending 50th anniversary of the IGY and the 125th anniversary of the first IPY, but the focus had not yet moved beyond celebration plans.

The first concrete plan for IPY 2007-2008 science was presented by Heinz Miller at the 2002 SCAR meeting in Shanghai (SCAR, 2002). Miller proposed a series of mul- tidisciplinary traverses along all the major ice divides of East Antarctica. The SCAR delegates supported a proposal to develop a "celebration." In late 2002 the U.S. National Academy of Sciences Polar Research Board convened a one-day international workshop addressing the question of whether an IPY was an applicable framework for science in 2007. Workshop participants strongly supported the IPY concept, and within the next six months the U.S. National Academies began the planning process in the United States (Albert, 2004). Simultaneously Chris Rapley and Robin Bell submitted a proposal to the International Council for Science (ICSU) Executive Committee to form a planning committee for the IPY. ICSU approved the proposal and the Planning Committee met for the first time in August 2003. The planning had moved past a celebration to setting a science agenda for a major international interdisciplinary effort (Figure 4).

Independently a group at the World Meteorological Organization (WMO), a sponsor of the earlier IPYs, had begun considering involvement in the proposed IPY 20072008. WMO joined the ICSU planning process in an advisory role. With the completion of the framework document (Rapley and Bell, 2004), the ICSU Planning Committee's work was complete. Together ICSU and WMO formed a new joint steering group called the Joint Committee, with 


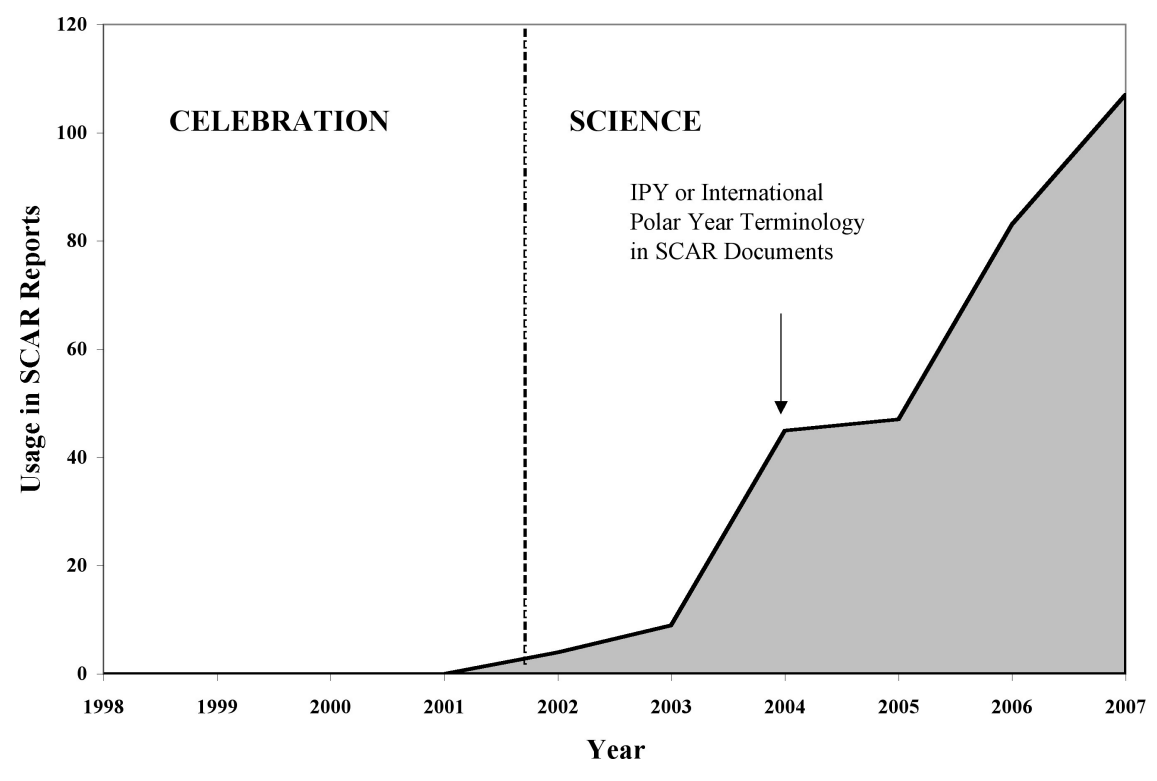

FIGURE 4 Emergence of International Polar Year 2007-2008 as documented in SCAR reports. Usage of the terms "IPY" and "International Polar Year" in SCAR reports from 1998 to 2007. Discussion focused on a celebration until 2002, when the emphasis became science. two co-chairs with representation from ICSU and WMO. A competition for an IPY International Program Office (IPO) was announced, and the successful bid was submitted by the British Antarctic Survey. An executive director for the IPY was hired, and the IPY 2007-2008 moved from the design phase to the implementation phase.

The implementation phase required that the Joint Committee develop a process to review the proposed work for the IPY 2007-2008 and develop a science plan. In due course the Joint Committee reviewed over 300 proposals that form the core of the IPY Science Program. The committee worked with the authors of proposals to ensure that many smaller projects could be accommodated under larger umbrella projects, like CASO (Climate of Antarctica and the Southern Ocean), which includes several smaller projects that started as Letters of Intent, but all contribute to the overall CASO goal. The aim was to encourage development of a relatively small number of large projects that would "make a difference."

Development of the project proposals was not top-down but a direct result of the community input. Taken together the 300 or so projects can be seen to make up a comprehensive and integrated science plan, which was published by the Joint Committee in 2007 (Allison et al., 2007). In March 2007 the polar year opened around the globe with events in over 30 nations signaling the beginning of two years of intensive polar observation and analysis. This current year is just the beginning.

\section{THEMES}

This four-year grassroots planning process defined six scientific themes that are the essential framework for IPY 2007-2008:
1. Status: Determine the present environmental status of the polar regions;

2. Change: Quantify and understand past and present natural, environmental, and social change in the polar regions and improve projections of future change;

3. Global Linkages: Advance understanding on all scales of the links and interactions between the polar regions and the rest of the globe and of the controlling processes;

4. New Frontiers: Investigate the frontiers of science in the polar regions;

5. Vantage Point: Use the unique vantage point of the polar regions to develop and enhance observatories from the interior of Earth to the sun and the cosmos beyond; and

6. The Human Dimension: Investigate the cultural, historical, and social processes that shape the sustainability of circumpolar human societies and identify their unique contributions to global cultural diversity and citizenship.

The first three themes-Status, Change, and Global Linkages - capture the changing planet, with an emphasis on changing climate at all times and scales (Figure 5 as the red triangle, or delta symbol). The majority of IPY 2007-2008 projects address these themes. The fourth-New Frontiers, or the exploration and discovery theme-has its largest projects in Antarctic Earth sciences as predicted by Odishaw at the close of the IGY. These frontiers in Earth science are primarily beneath the ice sheet or beneath the ocean floor (blue box at the base of Figure 5). The Vantage Point theme encompasses everything from observatories to examine the inner core to telescopes monitoring distant galaxies. The Human Dimension theme of this IPY 2007-2008 has a strong presence in the north but is not developed in the south due to the absence of a large permanent human population there. 

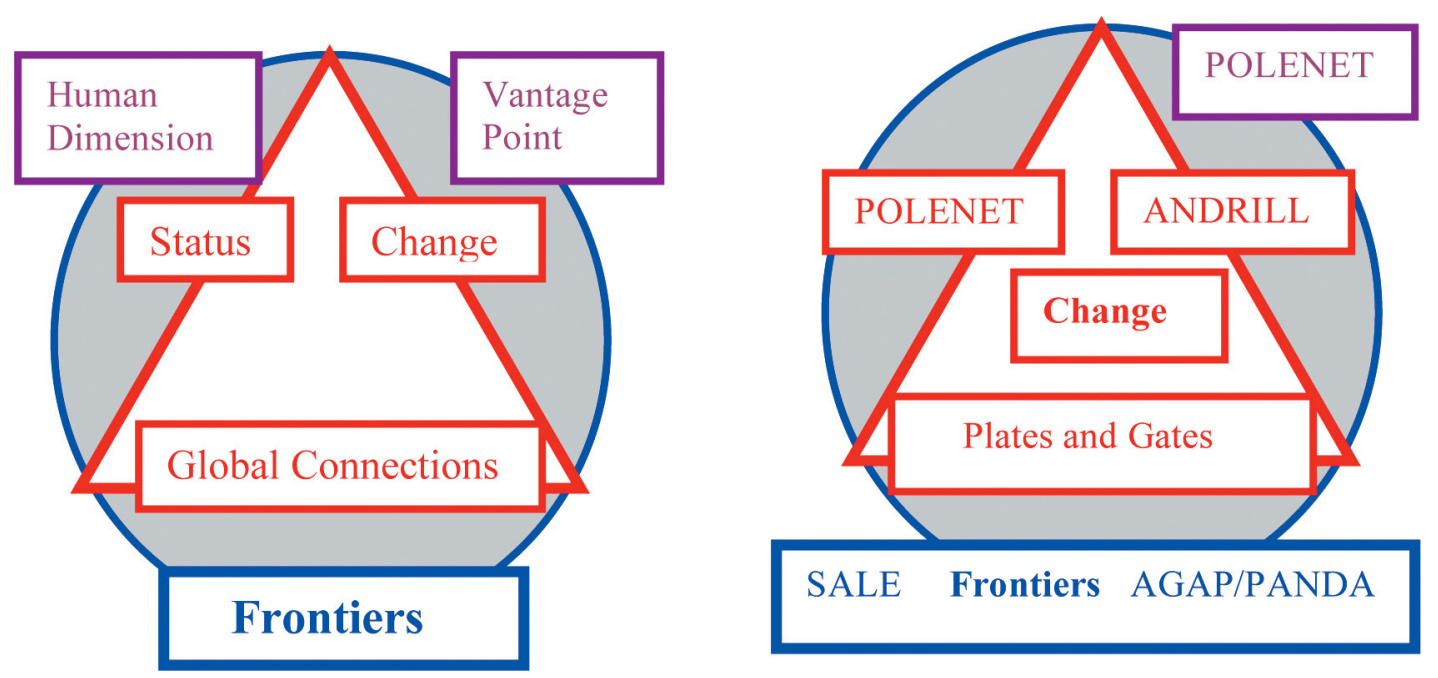

FIGURE 5 Left: Schematic of major IPY 2007-2008 themes. Right: Mapping major Antarctic Earth science projects.

\section{MAJOR INTERNATIONAL POLAR YEAR EARTH SCIENCE PROJECTS}

The principal IPY 2007-2008 Antarctic Earth science projects address change and all its components and exploration of new frontiers. The Antarctic Earth science components of the IPY 2007-2008 are primarily found within the Earth, land, and ice sector of the framework (Allison et al., 2007). Twelve projects fall into the category of Antarctic Earth sciences (Table 1).

Many of these projects are inherently interdisciplinary. This paper highlights five large projects that capture the breadth of the IPY 2007-2008 Earth science programs, both in terms of the time periods they address and in terms of their geographic locations. POLENET (Polar Earth Observing Network) will be implemented in both polar regions and will capture the tectonic and isostatic status of the Antarctic plate. POLENET is the major Antarctic Earth science project under the Status theme.

ANDRILL (Antarctic Geologic Drilling), which in late 2006 recovered the longest rock core in Antarctica, is a highly visible element of the Antarctic Climate Evolution (ACE) program, which integrates modeling studies and observational data from the Antarctic margin to resolve the continent's paleoenvironmental history. ANDRILL together with ACE clearly illustrate both the Change theme and the Global Linkages theme, as they examine the teleconnections between Northern and Southern Hemisphere climate change.

"Plates and Gates," by focusing on the tectonic and sedimentary formation of ocean gateways that are critical for controlling major water masses and global change, is a clear example of an investigation of the global linkages between polar processes and global climate. SALE-UNITED and the
AGAP/PANDA projects, which target the origin, evolution, and setting of subglacial lakes and the Gamburtsev subglacial highlands and the structure of the Dome A region, are both clear examples of the New Frontiers theme. As the POLENET observatories will include components capable of examining structure deep within Earth's interior, that project is also emblematic of the Vantage Point theme.

\section{POLENET}

POLENET is a consortium of scientists from 24 nations that will deploy a diverse suite of geophysical instruments aiming at interactions of the atmosphere, oceans, polar ice sheets, and Earth's crust and mantle (Figure 6). The POLENET teams will be deploying new GPS instruments, seismic stations, magnetometers, tide gauges, ocean-floor sensors, and meteorological recorders. The science program of the POLENET consortium will investigate polar geodynamics; Earth's magnetic field, crust, mantle, and core structure and dynamics; and systems-scale interactions of the solid Earth, cryosphere, oceans, and atmosphere. Activities will focus on the deployment of autonomous observatories at remote sites on the continents and offshore, coordinated with measurements made at permanent stations and by satellite campaigns. Geophysical observations made by POLENET will contribute to many branches of geoscience and glaciology. For example, sea-level and ice-sheet monitoring can be fully modeled only when measurements of solid Earth motions are incorporated. Both plate tectonic and paleoclimate studies benefit from crustal deformation results. POLENET's approach to install autonomous observatories collecting coordinated measurements captures Weyprecht's vision of coordinated observations from fixed stations. 
TABLE 1 Antarctic Earth Science IPY 2007-2008 Proposals from Scope of Science Report

\begin{tabular}{|c|c|c|}
\hline \multicolumn{2}{|c|}{ Proposal No. and Short Title } & \multirow{2}{*}{$\begin{array}{l}\text { Long Title } \\
\text { Antarctica's Gamburtsev Province; origin, evolution, and setting of the Gamburtsev subglacial } \\
\text { highlands; exploring an unknown territory }\end{array}$} \\
\hline 67 & AGAP & \\
\hline 256 & ANDRILL & $\begin{array}{l}\text { Antarctic Geologic Drilling: Antarctic continental margin drilling to investigate Antarctica's role in } \\
\text { global environmental change }\end{array}$ \\
\hline 109 & Rift System Dynamics & $\begin{array}{l}\text { Geodynamics of the West Antarctic Rift System and its implications for the stability of the West } \\
\text { Antarctic ice sheet }\end{array}$ \\
\hline 77 & Plates and Gates & Plate tectonics and polar ocean gateways \\
\hline 152 & IDEA & Ice Divide of East Antarctica: Trans-Antarctic Scientific Traverses expeditions \\
\hline 185 & POLENET & Polar Earth Observing Network \\
\hline 886 & USGS & U.S. Geological Survey: Integrated Research \\
\hline 54 & $\mathrm{ACE}$ & Antarctic Climate Evolution \\
\hline 97 & ICECAP & Investigating the Cryospheric Evolution of the Antarctic Plate \\
\hline 33 & ANTPAS & Antarctic Permafrost and Soils \\
\hline 313 & PANDA & The Prydz Bay, Amery Ice Shelf, and Dome-A Observatories \\
\hline 42 & SALE-UNITED & Subglacial Antarctic Lake Environments-Unified International Team for Exploration and Discovery \\
\hline
\end{tabular}
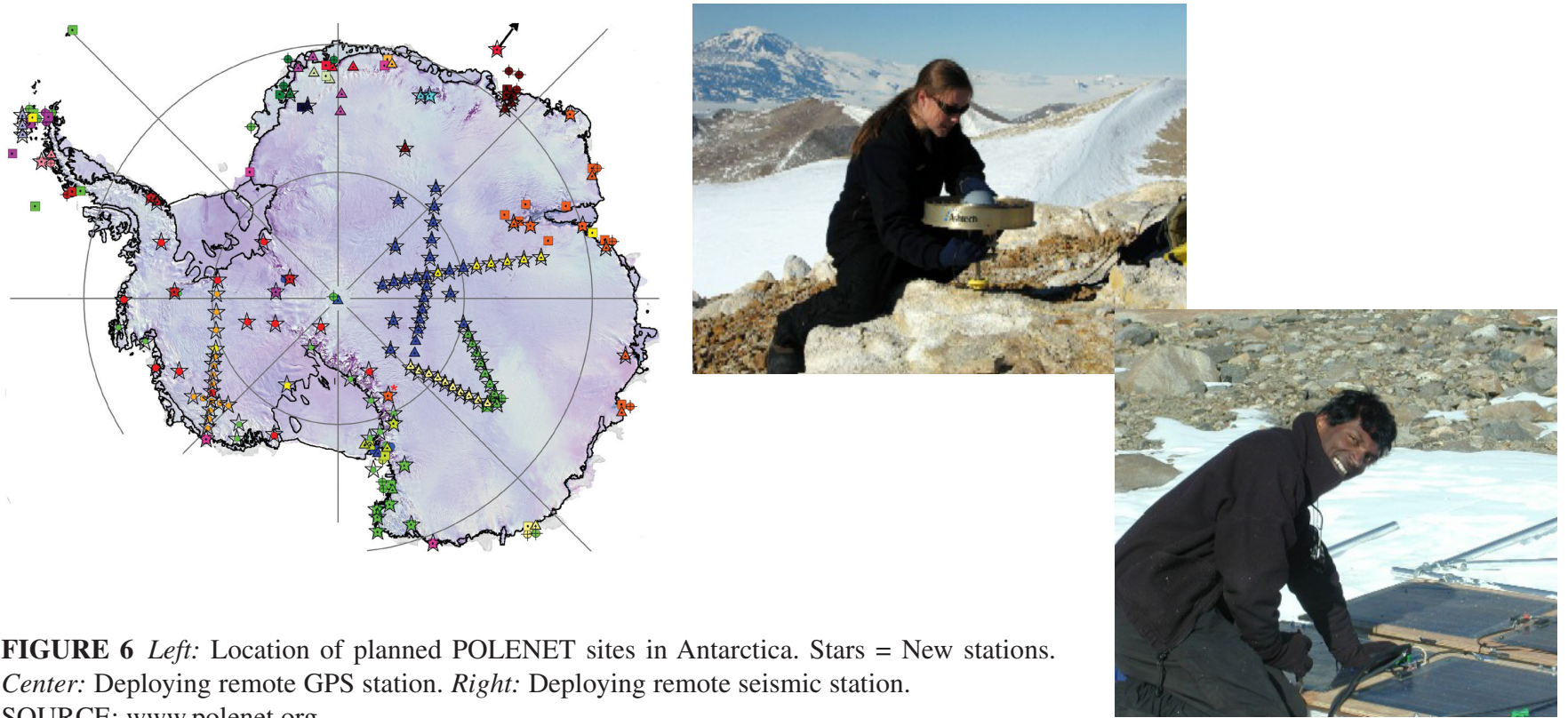

FIGURE 6 Left: Location of planned POLENET sites in Antarctica. Stars = New stations Center: Deploying remote GPS station. Right: Deploying remote seismic station. SOURCE: www.polenet.org.

\section{ANDRILL}

ANDRILL is the latest of a series of floating-ice-based drilling projects on the Antarctic margin, complementing ship-based projects that date back to Deep Sea Drilling Project Leg 28 in 1972 (Figure 7). ANDRILL is a multinational collaboration of more than 200 scientists, students, and educators from Germany, Italy, New Zealand, and the United States; it is also the largest Antarctic Earth science IPY 2007-2008 project targeting the Change and global linkages themes.

ANDRILL is an example of a major international project that developed in parallel with the IPY 2007-2008 planning and became an integral part of the IPY 2007-2008 program. ANDRILL is a scientific drilling project investigating Antarctica's role in global climate change over the last 60 million years. Employing new drilling technology designed specifically for ice-shelf conditions as well as state-of-the-art core analysis and ice-sheet modeling, ANDRILL addresses four scientific issues: (1) the history of Antarctica's climate and ice sheets; (2) the evolution of polar biota and ecosystems; (3) the timing and nature of major tectonic and volcanic episodes; and (4) the role of Antarctica in Earth's ocean-climate system. ANDRILL's goal is to drill a series of holes in the McMurdo Sound area in regions that have previously been inaccessible to ship-based drilling technologies. The strati- 

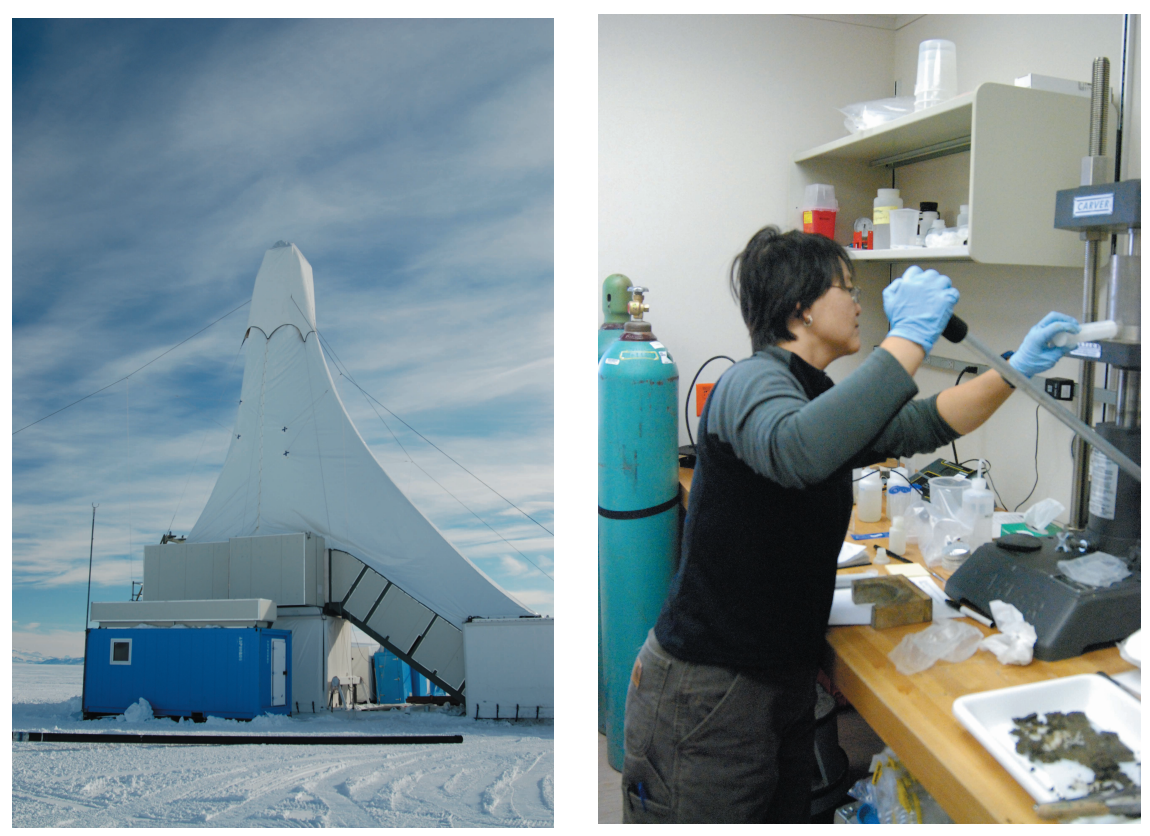

FIGURE 7 Top left: ANDRILL drill rig in the McMurdo Sound. Top right: Conducting core analysis on site. Bottom: Core in core trays. SOURCE: Images are from www.andrill.org.

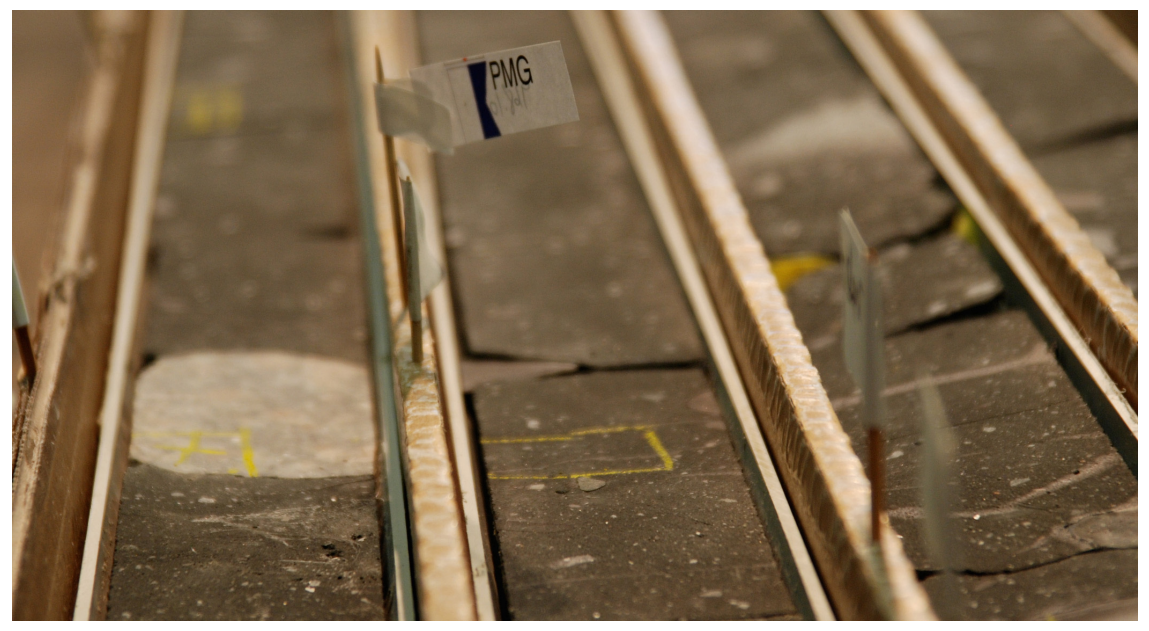

graphic records retrieved from these boreholes will cover critical time periods in the development of Antarctica's major ice sheets. The sediment cores will be used to construct an overall glacial and interglacial history for the region, including documentation of sea-ice coverage, sea level, terrestrial vegetation, and meltwater discharge events. The cores will also provide a general chronostratigraphic framework for regional seismic studies to help unravel the area's complex tectonic history. The first borehole was drilled in 2006-2007, and drilling the second borehole will begin in the 2007-2008 field season.

\section{Plates and Gates}

"Plates and Gates" is a multidisciplinary project aimed at understanding key polar oceanographic gateways for major water masses. Ocean gateways are the deepwater passageways that form as continents rift apart and that are destroyed when ocean basins close (Figure 8). As part of the global ocean circulation, water masses move through these passageways, and major shifts in the ocean gateways produce changes in the transport of heat, salt, and nutrients. These changes in global ocean circulation may trigger changes in global climate. Plates and Gates will establish detailed tectonic, geodynamic, sedimentary, and paleotopographic histories of major oceanic gateways, providing basic constraints for global climate modeling. In Antarctica, key areas are the Drake Passage and the former Tasman Gateway, the last barriers to the establishment of the Antarctic Circumpolar Current. The Antarctic Circumpolar Current is the fundamental vehicle for mass flux between the Pacific, Atlantic, and Indian oceans and has the largest flux of all the globe's ocean 


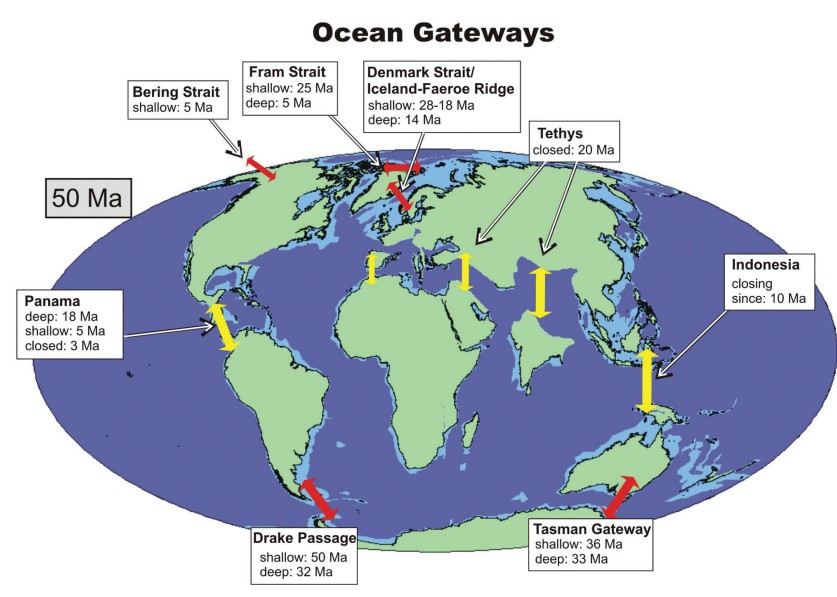

FIGURE 8 Plates and Gates. Left: Major ocean gateways influencing ocean circulation (from R. Livermore, British Antarctic Survey). Right: Alfred Wegner Institute's R/V Polarstern (from K. Gohl, Alfred Wegner Institute).

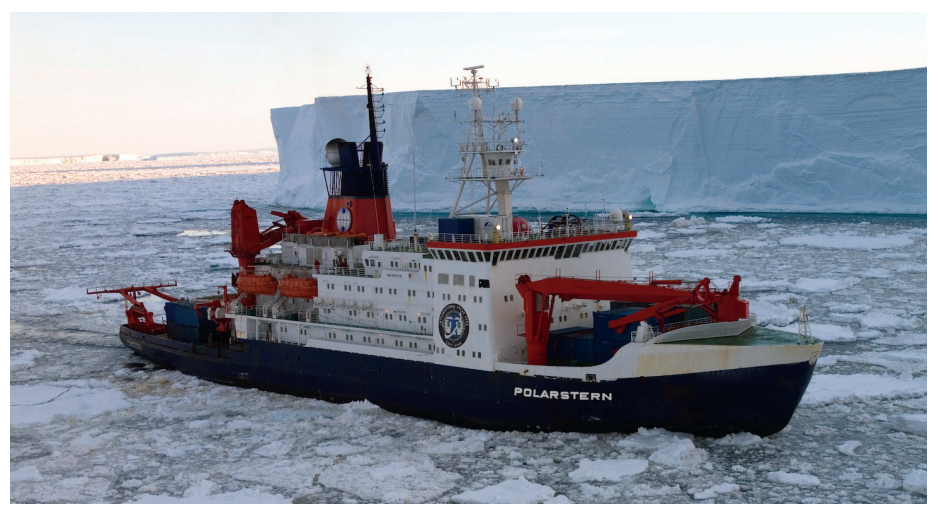

currents. The establishment of this large global ocean current has been suggested as one of the major triggers for the onset of Antarctic glaciation (Kennett, 1977). Field projects and modeling will be linked from the beginning to yield a model of the present status of water mass exchange in these regions, development of "gateway flow dynamics models" as well as a new range of high-resolution paleooceanographic and paleoclimate models. Plates and Gates will employ a coupled ocean atmosphere general circulation model to examine the impact of opening and closing of high- and low-latitude gateways on Eocene-Oligocene and Pliocene-Pleistocene climate changes. This project started in January 2007 with an expedition onboard the R/V Polarstern.

\section{AGAP and PANDA}

AGAP and PANDA together are a multinational, multidisciplinary aerogeophysical, traverse, and passive seismic instrumentation effort to explore East Antarctic ice-sheet history and the lithospheric structure of the Gamburtsev Subglacial Mountains (see Figure 9). AGAP and PANDA together assembled scientists from six nations to launch the IPY 2007-2008 Gamburtsev Subglacial Mountains Expedition. The Gamburtsev Subglacial Mountains are a major mountain range, larger than the Alps but virtually unexplored since they were discovered during the IGY in 1958. The Gamburtsev Subglacial Mountains are a 400-kmwide elevated massif rising 2000-3000 $\mathrm{m}$ above the regional topography and resting beneath the ice divide at Dome A, the highest plateau of the Antarctic ice sheet. While both the age and origin of the Gamburtsev Mountains in the framework of Antarctic and Gondwana tectonics has been a matter of considerable speculation, this unusual mountain range has been advanced as the nucleation point for two continentalscale glaciations, one in the late Paleozoic and one in the Cenozoic. The Gamburtsev Subglacial Mountains today are encased beneath 1 to $4 \mathrm{~km}$ of continental ice, but their role in ice-sheet dynamics, specifically as the nucleation point for continental-wide glaciation, remains speculative given our lack of knowledge about their age and origin.

AGAP will use aircraft and surface instrumentation to collect major new datasets, including gravity, magnetics, ice radar, and other geological observations. The airborne team (GAMBIT) will acquire an extensive new airborne dataset, including gravity, magnetics, ice thickness, synthetic aperture radar images of the ice-bed interface, near-surface and deep internal layers, and ice surface elevation. The nested survey design will include a dense high-resolution survey over Dome A augmented by long regional lines to map the tectonic structures. The interpretation of these datasets will advance our understanding of ice-sheet dynamics, subglacial lakes, and Antarctic tectonics. The seismic team (GAMSEIS) will deploy portable broadband seismographs to examine the seismic structure of the crust and upper mantle. The PANDA transect from Prydz Bay-Amery Ice Shelf-Lambert Glacier Basin-Dome A covers an interconnected ocean, ice-shelf, and ice-sheet system, which plays a very important role in East Antarctica mass balance, sea level, and climate change. 

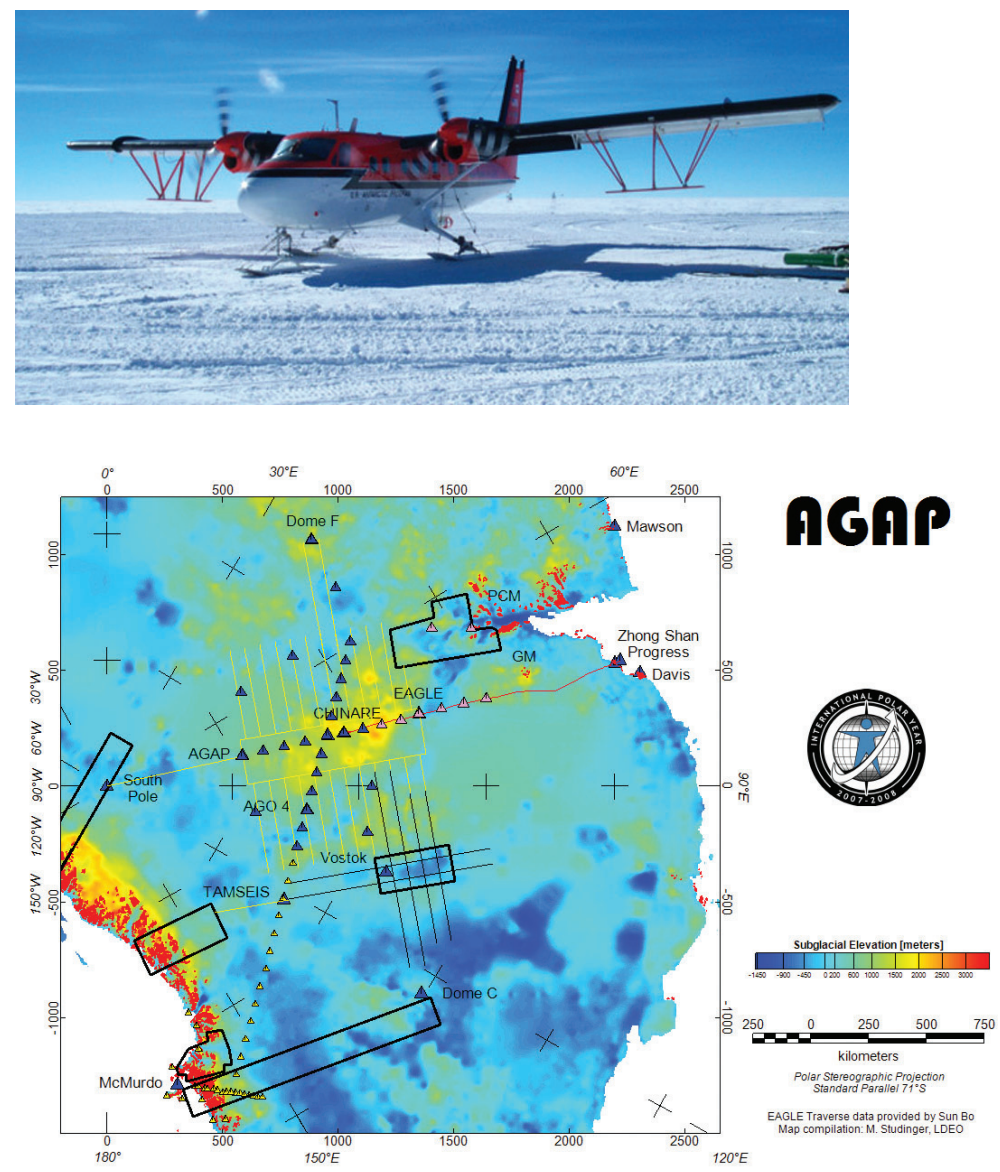

FIGURE 9 Top: Aerogeophysical Twin Otter in East Antarctica. Bottom: AGAP survey design over ice surface (yellow grid).

SOURCE: Images are from M. Studinger, LamontDoherty Earth Observatory.

\section{SALE-UNITED}

SALE-UNITED is a federation of interdisciplinary researchers who will conduct expeditions to explore all facets of subglacial lake environments under the New Frontiers theme during the IPY 2007-2008 (Figure 10). The SALE-UNITED research and exploration project will investigate subglacial lake environments of differing ages, evolutionary histories, and physical settings. These comparative studies will provide a holistic view of subglacial environments over millions of years and under differing climatic conditions. Included in the SALE-UNITED IPY 2007-2008 projects will be the drilling into Lake Vostok in 2008-2009, acquisition of surface geophysics over Lake Ellsworth in West Antarctica and Lake Concordia near Dome Concordia, and acquisition of both airborne and surface geophysics over the Recovery Lakes in Queen Maud Land. Each one of these projects represents a major advance in the study of subglacial lakes. The successful recovery of water from drilling into Lake Vostok will provide key new insights into the fundamental questions as to the basic nature of the water in the lakes and whether life can be supported in the water column. Lakes Ellsworth and Concordia are also targeted for sampling. The surface geophysics acquired during IPY 2007-2008 will provide seismic constraints on the volume of water and the processes within these lakes. The Recovery Lakes appear to be triggering the onset of rapid ice flow into the Recovery Ice Stream (Bell et al., 2007). Seismic data collected by the U.S.-Norwegian traverse team will provide insights into the volume of subglacial water, while the airborne geophysics will constrain the flux of ice and water through the system. Additionally, the SALEUNITED group will conduct genomic studies of accreted ice and modeling of lake stability. Together these projects will advance our understanding of the subglacial lake environment and the role lakes play in ice-sheet stability.

\section{AN INTEGRATED VISION FOR ANTARCTIC EARTH SCIENCE IN THE IPY 2007-2008}

The five major projects described above capture the major IPY 2007-2008 themes that were defined in the planning process. Together they illustrate the breadth of the Antarctic Earth science programs for the IPY 2007-2008. While at first glance these projects may appear to be narrowly focused on climate, they capture the entire scope of major Antarctic geophysical events (Table 2). For example, AGAP and PANDA will be targeting the basic cratonic structure of East Antarctica, structures that likely formed during the assembly of Rodinia and other key events early in the history of the Antarctic continent. Plates and Gates focuses on the 

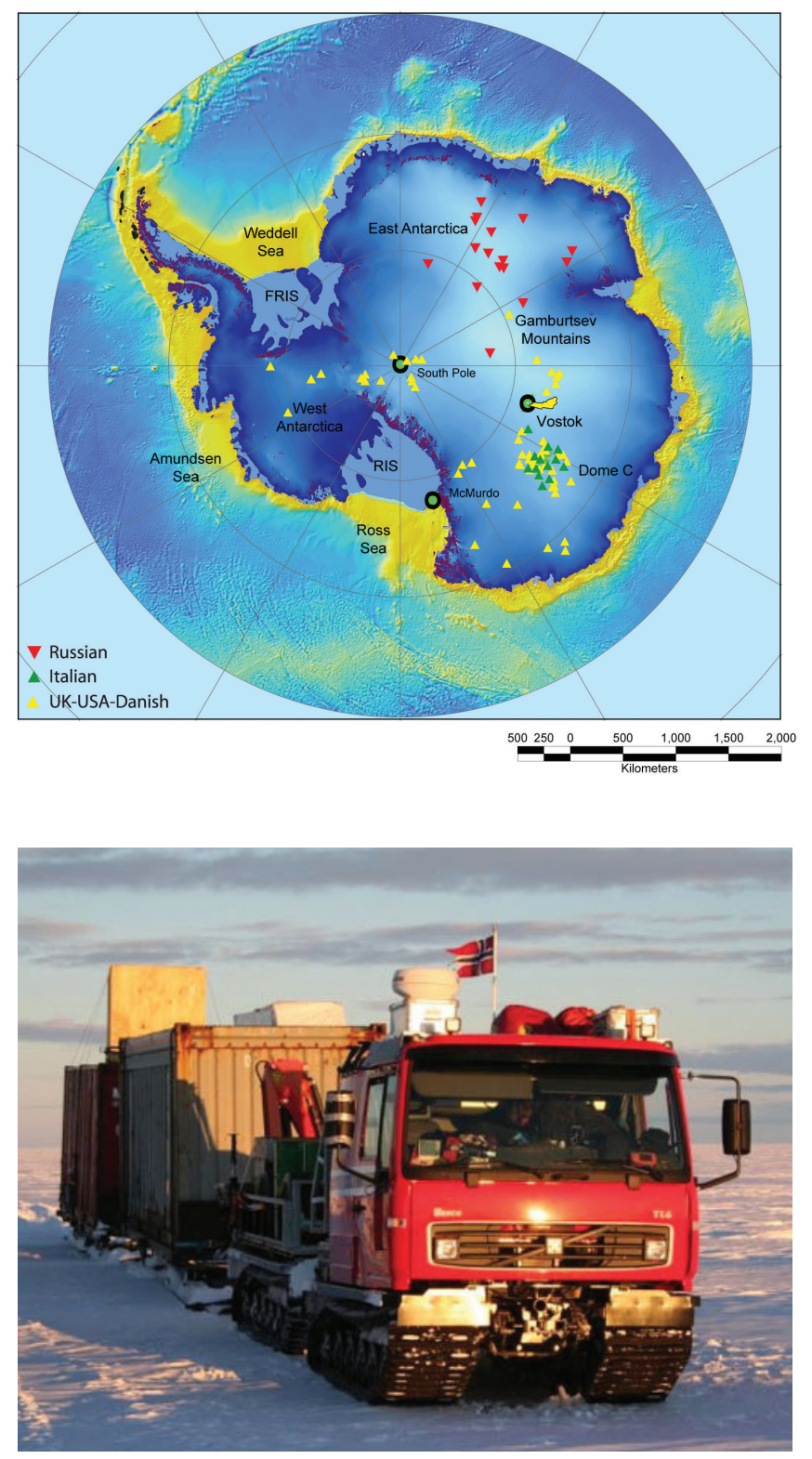

FIGURE 10 Top: SALE-UNITED. Location of subglacial lakes (from M. Studinger, http://www.ldeo.columbia.edu/ mstuding/ vostok.html) Bottom: Traverse vehicles for U.S.-Norwegian traverse of the Recovery Lakes (from Norwegian Polar Institute). break-up of Gondwana and the subsequent formation of the ocean gateways between continental fragments. Both AGAP and POLENET will contribute to resolving the history of extension in the Ross Sea, while controls on Transantarctic Mountains uplift will be elucidated by both Plates and Gates and ANDRILL. The origin, history, and stability of the Antarctic ice sheets will be addressed by all these projects.

\section{OUTSTANDING CHALLENGES}

As of this writing we are still at an early stage of the IPY 2007-2008, less than six months after the official opening in Paris and around the globe on March 1, 2007. Since the identification of funding for national components of IPY 20072008-approved projects is still ongoing in many countries, it remains difficult to fathom the full breadth of the IPY 20072008. But several hundred million dollars of new money for polar science is already available, and more is likely.

Even at this early stage it is useful to consider the pitfalls that other IPYs have encountered that prevented them from realizing their full potential. The results of the first IPY were never fully realized because each nation worked to publish their data individually. The data were not openly shared, and long-term collaboration between nations did not materialize. In our more electronically connected world there is little excuse for data not to be openly shared and deposited in the appropriate data repository so that future generations can make use of this precious resource.

Building collaborations within a discipline is simple. The challenge for this IPY 2007-2008 is to establish longlasting, effective working relationships across disciplines. Many of the projects contain the seeds of these difficult multidisciplinary relationships, whether between modelers and field scientists or between biologists and geophysicists. These interactions must be fostered and developed. Collaborations built on shared data and shared passions in Earth systems are essential. Interdisciplinary science is difficult, but it will be the only way Earth science will remain relevant to society, and it is the only way to gain the full return from our investment. True, open interdisciplinary collaboration will serve to advance our understanding of the poles and the role they play in our planetary system.

TABLE 2 Five Major Antarctic Geophysical Events Targeted by IPY 2007-2008 Programs

\begin{tabular}{|c|c|c|c|c|c|}
\hline $\begin{array}{l}\text { Major } \\
\text { Event }\end{array}$ & $\begin{array}{l}\text { Formation of East } \\
\text { Antarctic Craton }\end{array}$ & $\begin{array}{l}\text { Breakup of } \\
\text { Gondwana }\end{array}$ & $\begin{array}{l}\text { Extension of the } \\
\text { Ross Sea }\end{array}$ & $\begin{array}{l}\text { Uplift of the } \\
\text { Transantarctic } \\
\text { Mountains }\end{array}$ & $\begin{array}{l}\text { Origin, History, Status, } \\
\text { Stability of Antarctic Ice } \\
\text { Sheets }\end{array}$ \\
\hline $\begin{array}{l}\text { IPY } \\
\text { 2007-2008 } \\
\text { Programs }\end{array}$ & $\begin{array}{l}\text { AGAP, } \\
\text { PANDA }\end{array}$ & Plates and Gates & $\begin{array}{l}\text { ANDRILL, } \\
\text { POLENET }\end{array}$ & $\begin{array}{l}\text { ANDRILL, } \\
\text { Plates and Gates }\end{array}$ & $\begin{array}{l}\text { AGAP, PANDA, } \\
\text { ANDRILL, } \\
\text { Plates and Gates, } \\
\text { POLENET, } \\
\text { SALE-UNITED }\end{array}$ \\
\hline
\end{tabular}




\section{ANTICIPATED OUTCOMES}

This IPY 2007-2008 marks the beginning of a new era in polar science that will routinely involve cooperation between a wide range of research disciplines from geophysics to ecology. While much of our science today is international, the IPY 2007-2008 is truly the largest international scientific endeavor of any kind that most of us will ever witness. Just as many of today's leaders in science and engineering entered these fields because of the IGY, the next generation will be captivated by the powerful science projects of the IPY $2007-$ 2008. The IPY 2007-2008 will open new frontiers, specifically East Antarctica and the subglacial environment, to the international scientific community. From the IPY 2007-2008 will emerge new collaborative frameworks for science that will continue to enable each of us to accomplish more than we could have accomplished as individual scientists or as individual nations.

\section{REFERENCES}

Albert, M. R. 2004. The International Polar Year. Science 303(5663): 1437.

Allison, I. B. M. et al. 2007. The scope of science for the International Polar Year 2007-2008. World Meterologic Organization Technical Document No. 1364, 81 pp. Geneva: World Meterologic Organization.

Bell, R. E., M. Studinger, C. A. Shuman, M. A. Fahnestock, and I. Joughin. 2007. Large subglacial lakes in East Antarctica at the onset of fastflowing ice streams. Nature 445(7130):904-907.

Domack, E., D. Duran, A. Leventer, S. Ishman, S. Doane, S. McCallum, D. Amblas, J. Ring, R. Gilbert, and M. Prentice. 2005. Stability of the Larsen B Ice Shelf on the Antarctic Peninsula during the Holocene epoch. Nature 436(7051):681-686.

Greely, A. W. 1886. Report on the Proceedings of the United States expedition to Lady Franklin Bay, Grinnell Land. Washington, D.C.: U.S. Government Printing Office.

Johannessen, O. M., E. V. Shalina, V. Elena, and M. W. Miles. 1999. Satellite evidence for an Arctic sea ice cover in transformation. Science 286(5446):1937-1939.
Joughin, I., E. Rignot, C. E. Rosanova, B. K. Lucchitta, and J. Bohlander. 2003. Timing of recent accelerations of Pine Island Glacier, Antarctica. Geophysical Research Letters 30(13):1706.

Kennett, J. P. 1977. Deep-sea drilling contributions to studies of evolution of Southern-Ocean and Antarctic glaciation. Antarctic Journal of the United States 12(4):72-75.

Nansen, F., and O. N. Sverdrup. 1897. Farthest North: Being the Record of a Voyage of Exploration of the Ship "Fram" 1893-96, and of a Fifteen Months' Sleigh Journey by Dr. Nansen and Lieut. Johansen. New York: Harper.

Odishaw, H. 1959. "The Meaning of the International Geophysical Year," U.S. President's Committee on Information Activities Abroad (Sprague Committee) Records, 1959-1961, Box 6, A83-10, Dwight D. Eisenhower Library, Abilene, Kansas.

Rapley, C., and R. E. Bell. 2004. A Framework for the International Polar Year 2007-2008. Paris: ICSU.

Rignot, E., G. Casassa, P. Gogineni, W. Krabill, A. Rivera, and R. Thomas. 2004. Accelerated ice discharge from the Antarctic Peninsula following the collapse of Larsen B Ice Shelf. Geophysical Research Letters 31(18).

Scambos, T. A., J. A. Bohlander, C.A. Shuman, and P. Skvarca. 2004. Glacier acceleration and thinning after ice shelf collapse in the Larsen B embayment, Antarctica. Geophysical Research Letters 31(18).

SCAR. 2002. Scientific Committee on Antarctic Research Bulletin, Cambridge, Scientific Committee on Antarctic Research 149:1-16.

Shepherd, A., D. Wingham, A. Payne, and P. Skvarca. 2004. Warm ocean is eroding West Antarctic ice sheet. Geophysical Research Letters 31(23).

Steen, A. S. 1887. Die internationale Polarforschung, 1882-1883. Beobachtungs-Ergebnisse der Norwegischen Polarstation Bossekop in Alten. Christiania: Grödahl \& Sons. 2 vols.

Steffen, K., S. V. Nghiem, R. Huff, and G. Neumann. 2004. The melt anomaly of 2002 on the Greenland ice sheet from active and passive microwave satellite observations. Geophysical Research Letters 31(20).

Weyprecht, L. K. 1875. Scientific work of the Second Austro-Hungarian Polar Expedition, 1872-4. Journal of the Royal Geographical Society of London 45:19-33.

Wood, K. R., and J. E. Overland. 2006. Climate lessons from the first International Polar Year. Bulletin of the American Meteorological Society 87(12):1685-1697. 